\title{
A NEW SPECIES OF MICROCHILUS (ORCHIDACEAE, GOODYERINAE) FROM PERU
}

\author{
Dariusz L. SzlachetKo \& Marta KolanowsKa ${ }^{1}$
}

\begin{abstract}
A new species of Microchilus C. Presl, M. leucostictus Rchb. f. ex Szlach. \& Kolan, is described and illustrated based on Peruvian material. The taxonomic affinities of the new entity are briefly discussed.
\end{abstract}

Key words: biodiversity, Neotropics, Erythrodes, taxonomy

Dariusz L. Szlachetko \& Marta Kolanowska, Department of Plant Taxonomy and Nature Conservation, University of Gdańsk, Wita Stwosza 59, 80-308 Gdańsk, Poland; e-mail: martakolanowska@wp.pl

\section{INTRODUCTION}

The taxonomic position of subtribe Goodyerinae (Orchidaceae) and the delimitation of genera within it have been a topic of discussion since Schlechter's (1911) proposed classification of Polychondreae. Representatives of Goodyerinae are found in both the Neotropics and Paleotropics but their greatest diversity is observed in tropical Asia (Dressler 1993). The New World species usually have been classified in Erythrodes Blume or its later illegitimate synonym Physurus A. Rich. ex Lindl., but recent research has completely altered their taxonomic affiliation (Garay 1977; Ormerod 2002). Erythrodes is currently recognized as being restricted to the Asian Old World tropics, while its Neotropical species were placed in the genera Aspidogyne Garay, Kreodanthus Garay, Ligeophila Garay, Platythelys Garay, and, most of all, Microchilus C. Presl. All members of Physurus have been variously transferred to Aspidogyne or Microchilus.

The largest Neotropical genus of Goodyerinae is Microchilus, the diversity of which was long unrecognized. Recent studies of the genus by Ormerod (2002, 2005, 2007, 2008, 2009a, b, 2013) resulted in numerous transfers and descriptions of new species. Many taxa are known from single localities or very restricted areas. What is interesting

\footnotetext{
1 Corresponding author
}

is that the species are usually well distinguished morphologically, especially when the lip, column, and spur form are considered. These features suggest adaptation to various pollinators as one factor playing a major role in speciation of Microchilus. Representatives of Microchilus produce decumbent rhizomes that are rooted at the nodes. The petioles of the cauline leaves are expanded basally into infundibuliform sheaths. The resupinate, small, rather delicate flowers are arranged into a pedunculate, spicate or racemose inflorescence. The petals are connivent with the dorsal sepal, forming a hood or tube over the gynostemium. The lip is bipartite, with epichile lobules being commonly reflexed. The lip hypochile is marginally adnate to the sides of the gynostemium, basally formed into a distinct spur of various shapes. The erect gynostemium is an elongate, slender foot. The anther varies from ovate to lanceolate and is biloculate. The pollinia are sectile, sometimes with smooth outer surfaces, and are attached by their inner margins to the upper side of a linear-clavate viscidium. The stigma lobes are ventral, confluent, entire to bilobed, and usually flat. The rostellum is triangular to oblong and the rostellum remnant is deeply bifid.

The gynostemium, especially the pollinarium, is one of the most important characters discrimi- 
nating Neotropical Microchilus from Asian Erythodes. The latter is characterized by its shallowly bifid rostellum and bipartite pollinia with a single groove.

Microchilus species usually grow as terrestrial plants in lowland and montane forest up to $3000 \mathrm{~m}$ a.s.1.; an example is $M$. platysepalus Ormerod (Ormerod \& Cribb 2003). The genus embraces ca 135 species distributed from Argentina to Mexico and the Caribbean, with the greatest species diversity observed in northern South America (especially Colombia). Schweinfurth (1958) reported the occurrence of 17 'Erythrodes' species in Peru but only five of these taxa are currently recognized as belonging in Microchilus. The others are classified under Aspidogyne (6), Ligeophila (4), Platythelys (1) and Kreodanthus (1). Recent revisions of the genus revealed the existence of 14 new Peruvian species and yielded 2 new records of Microchilus (Ormerod 2002, 2005, 2007, 2008, 2009a), bringing the total number of species to 20 .

During our examination of orchid specimens deposited in Heinrich G. Reichenbach's herbarium in Vienna we came across distinctive plants identified by Reichenbach as Physyrus leucostictus. This name, which was never effectively published (Art. 29.1 ICN, McNeill et al. 2012), is here validated in Microchilus, with a description and illustration provided, along with notes on its taxonomic affinities.

\section{DESCRIPTION OF THE NEW SPECIES}

Microchilus leucostictus Rchb. f. ex Szlach. \& Kolan., sp. nov. Fig. 1

Species similar to Microchilus pedrojuanensis Ormerod but distinguished by having longer leaves, a shorter spur and longer hypochile.

Holotype: PERU. Cuchero. Jul 1829. Poeppig s.n. (W-R).

Plants $25 \mathrm{~cm}$ tall, rather delicate. Leaves 6; sheath and petiole to $1.2 \mathrm{~cm}$ long; blade to $6 \mathrm{~cm}$ long and $1 \mathrm{~cm}$ wide, obliquely oblong-lanceolate to narrowly lanceolate, acute, with bright stripe along midvein. Inflorescence $4 \mathrm{~cm}$ long, $c a 10$-flowered, subdense. Flowers small, sepals sparsely glandular- pubescent. Floral bracts 5-6 mm long, lanceolate to oblong-lanceolate, acute, densely glandularpubescent. Pedicellate ovary $6 \mathrm{~mm}$ long, densely glandular-pubescent. Sepals marginally agglutinate almost to apex. Dorsal sepal $4.3 \mathrm{~mm}$ long, $1 \mathrm{~mm}$ wide, ligulate-ovate, rounded and thickened at apex, concave in center, 1-nerved. Lateral sepals $4.6 \mathrm{~mm}$ long, $1 \mathrm{~mm}$ wide, obliquely ligulate to oblong, obtuse thickened at apex, 1-nerved. Petals $4 \mathrm{~mm}$ long, $0.9 \mathrm{~mm}$ wide, ligulate-oblanceolate, subacute-obtuse, 1-nerved. Lip hypochile $4 \mathrm{~mm}$ long, $1.2 \mathrm{~mm}$ wide, rectangular-pandurate in outline, concave at base, thickened along midvein; epichile $0.8 \mathrm{~mm}$ long, $3.5 \mathrm{~mm}$ wide, transversely ligulate in outline, obscurely 3-lobed, the middle lobe semicircular. Spur $4 \mathrm{~mm}$ long, $0.9 \mathrm{~mm}$ in diameter, cylindrical-clavate, attenuate towards apex.

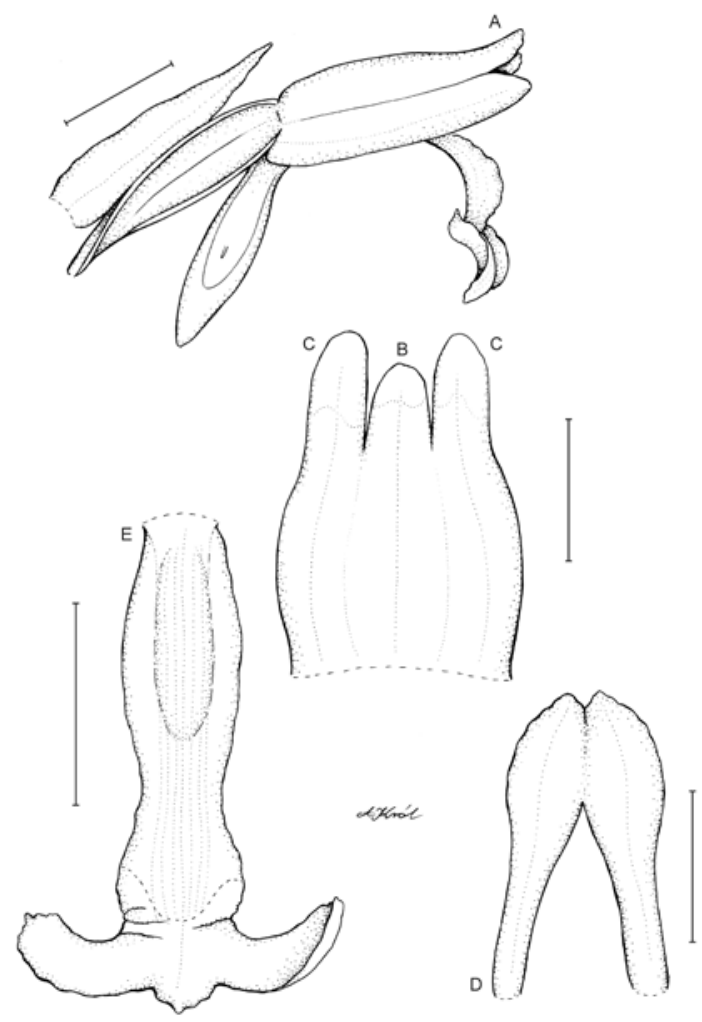

Fig. 1. Microchilus leucostictus Rchb. f. ex Szlach. \& Kolan., sp. nov. - dissected perianth. A - flower - lateral view, B - dorsal sepal, C - lateral sepals, D - petals, E - lip (drawn by Anna Król from holotype). Scale bars $=2 \mathrm{~mm}$. 
ETymology. From the Classical Greek leucus, meaning white or bright, and stictus, meaning spotted or marked, presumably in reference to the brightly striped leaves.

Distribution. So far this species in known only from the Andean region of central Peru, department of Huanúco, near the Huallaga River.

Notes. The new species belongs to the M. arietinus (Rchb. f. \& Warm.) Ormerod complex, a group of $\mathrm{ca} 17$ species distributed from Argentina to Mexico which was first recognized by Ormerod (2005). Within Microchilus this group may be recognized by its lanceolate to ovate leaves, often with a whitish to silver median stripe, a subdensely to laxly flowered inflorescence, and flowers with a slender, 3-4 mm long column. The center of diversity is Peru, from where 7 (6 endemic) species have already been reported.

The new species resembles Microchilus pedrojuanensis Ormerod (= M. rojasii Ormerod) from Paraguay and southern Brazil but differs from it in having longer leaves (blade to $6 \times 1 \mathrm{~cm}$ vs $2.5-4.2$ $\times 0.7-1.3 \mathrm{~cm}$ ), a shorter spur (4 vs $4.8-5.5 \mathrm{~mm}$ ) and longer labellum hypochile (4 vs 3.0-3.5 mm). Among the Peruvian species, M. leucostictus probably is most closely related to $M$. ensicalcar Ormerod since it has similarly short and narrow leaf blades (to $7 \times 1.4 \mathrm{~cm}$ ). However, M. ensicalcar has larger flowers (sepals $5.5-6.0 \mathrm{~mm}$ vs 4.3-4.6 mm), a cuneate-rectangular (vs subpandurate) hypochile, and a longer, ensiform spur (5.5-6.0 vs $4 \mathrm{~mm}$ and fusiform).

Two other species similar to M. leucostictus are rather widespread taxa: $M$. arietinus known with certainty from Argentina, Brazil and Bolivia, and M. constrictus Ormerod from Colombia, Brazil and Peru. Those two taxa differ from M. leucostictus in having broader leaves ( $\mathrm{ca} 2 \mathrm{~cm}$ wide or more) and in having flowers with narrowly cylindrical-oblongoid (vs fusiform), shorter (3.0-3.5 vs $4 \mathrm{~mm}$ ) spurs.
ACKNOWLEDGEMENTS. We thank the Curator and staff of the Herbarium of Natural History Museum in Vienna for their kind hospitality and assistance during visits, the anonymous reviewers for valuable suggestions on the manuscript, and Anna Król for preparing the illustrations. The paper is a part of a project supported by the Polish Ministry of Science and Higher Education (grant no. 8124/B/PO1/2011/40).

\section{REFERENCES}

DRESSLER R. L. 1993. Phylogeny and classification of the orchid family. Dioscorides Press, Portland.

Garay L. A. 1977. Systematics of the Physurinae in the new world. Bradea 2: 191-208.

McNeill J., Barrie F. R., Buck W. R., Demoulin V., Greuter W., Hawksworth D. L., Herendeen P. S., Knapp S., Marhold K., Prado J., Prud'homme van Reine W. F., Smith G. F., Weirsema J. H. \& Turland N. J. 2012. International Code of Nomenclature for algae, fungi, and plants (Melbourne Code). Regnum Veg. 154: [i]-xxx, 1-208.

Ormerod P. 2002. Taxonomic changes in Goodyerinae (Orchidoideae). Lindleyana 17: 189-238.

OrMERoD P. 2005. Studies of neotropical Goodyerinae (Orchidaceae). Harvard Pap. Bot. 9: 391-423.

Ormerod P. 2007. Studies of neotropical Goodyerinae (Orchidaceae) 2. Harvard Pap. Bot. 11: 145-177.

OrMerod P. 2008. Studies of neotropical Goodyerinae (Orchidaceae) 3. Harvard Pap. Bot. 13: 55-87.

Ormerod P. 2009a. Studies of neotropical Goodyerinae (Orchidaceae) 4. Harvard Pap. Bot. 14: 111-129.

Ormerod P. 2009b. Notulae Goodyerinae (IV). Taiwania 54: $45-51$.

Ormerod P. 2013. Studies of neotropical Goodyerinae (Orchidaceae) 5. Harvard Pap. Bot. 18: 51-60.

Ormerod P. \& CribB P. J. 2003. Microchilus. In: A. M. PridgEON, P. J. CRIBb, M. W. Chase \& F. N. Rasmussen (eds), Genera Orchidacearum 3: Orchidoideae (Part 2), Vanilloideae: 121-124. Oxford University Press, Oxford.

Schlechter R. 1911. Die Polychondreae (Neottiinae Pfitz.) und ihre systematische Einteilung. Bot. Jahrb. Syst. 45: 375-410.

Schweinfurth C. 1958. Orchids of Peru. Fieldiana, Bot. 30(1): $1-260$. 